\title{
CHRONIC TOXICITY AND TERATOLOGICAL TEST OF THIAMINE MONOPHOSPHATE DISULFIDE ${ }^{1}$
}

\author{
MASAKI HORI, YOSHIO NAKAYAMA, YUZO NOGUCHI \\ AND YOSHIO KOWA ${ }^{2}$ \\ Osaka Research Laboratory, Tanabe Seiyaku Co., Ltd., \\ Higashiyodogawa-ku, Osaka
}

(Received October 26 1965)

It was suggested from the foregoing paper that the toxicity of TMPDS was very low, because the $\mathrm{LD}_{50}$ value obtained by the acute toxicity test in mice after its intravenous administration as high as $6 \mathrm{~g} / \mathrm{kg}$. The authors investigated further on the chronic toxicity following its long-term administration and the influence on the fetus following its administration to mother animals. Thus its safety was definitely confirmed.

\section{EXPERIMENTAL AND RESULTS}

\section{Chronic Toxicity Test}

Methods - Wistar-King male rats, weighing about $110 \mathrm{~g}$, were used. They were divided into 3 groups, each group consisting of 20: $A$, receiving TMPDS equivalent to $50 \mathrm{mg} / \mathrm{kg}$ thiamine $\mathrm{HCl} ; B$, receiving TMPDS equivalent to $100 \mathrm{mg} / \mathrm{kg}$ thiamine- $\mathrm{HCl}$ and $C$, a control, receiving $1.5 \% \mathrm{NaHCO}_{3}$. Each of them was kept in a separate cage. Various amounts of TMPDS were each dissolved in $1.5 \%$ $\mathrm{NaHCO}_{3}$ and was administered intraperitoneally for 6 months. The body weight was weighed twice a week, the food intake for 6 days was determined once a month, and in addition, the general condition was observed. Six months after the administration, the haematological, anatomical and pathological were made. Rats were kept at $22 \pm 1^{\circ}$ and 55-60\% humidity and fed ad libitum with water and solid diet CA-1 prepared by Central Laboratories for Experimental Animals," Tokyo. The above doses were 50 and 100 times the normal human dose $(1 \mathrm{mg} / \mathrm{kg})$.

Results - Body weight change: The weight change for 6 months is shown in Fig. 1. During the experimental period, 4 in group $A, 5$ in $B$ and 4 in $C$ died. Each one in both groups $A$ and $B$ died by the mistake of injection. Others lost the luster of the hair and body weight, bled at the nose, and died of pneumonia. Pathological examinations revealed the marked pneumonic symptom, but no changes due to the drug were observed. No abnormalities were found in other rats.

Food Intake: The food consumption for 6 days was determined once a month. No difference was seen between the groups during the period of observation.

\footnotetext{
${ }^{1}$ Studies on Thiamine Monophosphate Disulfide. IV.

Following abbreviation is used: TMPDS, thiamine monophosphate disulfide.

2 淈正樹, 中山良夫, 野口祐三, 甲和良夫。
} 


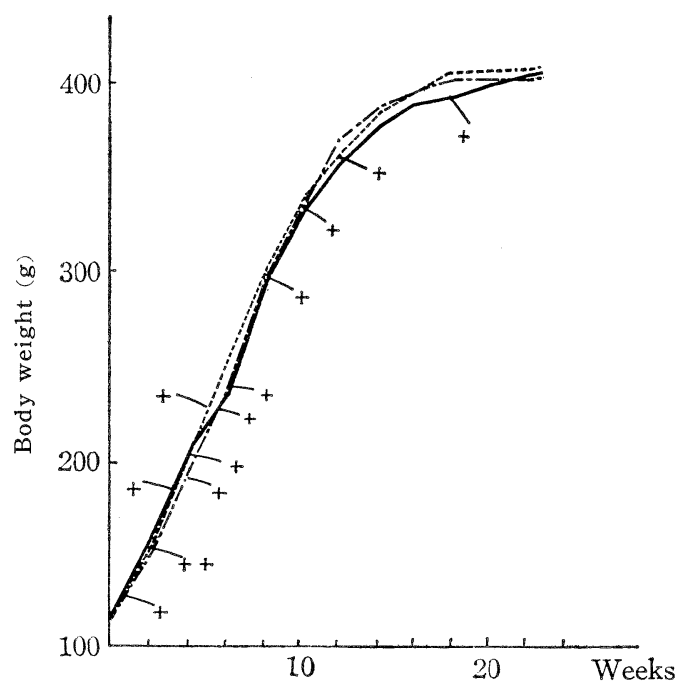

FIG. 1 Growth Curve of TMPDS Administration

-.-, TMPDS, $50 \mathrm{mg} / \mathrm{kg}$; -, TMPDS, $100 \mathrm{mg} / \mathrm{kg}$;

-.., control; +, case of death.

Hematological Findings: As shown in Table 1, no difference was found between the groups.

TABLE 1

Blood Findings

\begin{tabular}{llll}
\hline & Group A & Group B & Group C \\
\hline Number of erythrocytes $\left(\times 10^{4} / \mathrm{mm}^{3}\right)$ & $707 \pm 14^{a}$ & $675 \pm 18$ & $679 \pm 23$ \\
Number of leucocytes $\left(\times 10^{2} / \mathrm{mm}^{3}\right)$ & $114 \pm 5$ & $114 \pm 8$ & $126 \pm 13$ \\
Hemoglobin value $(\%)$ & $15.8 \pm 0.3$ & $15.2 \pm 0.7$ & $16.6 \pm 0.2$
\end{tabular}

${ }^{a}$ Standard error.

Weight of Organs: As shown in Table 2, no difference was found between the groups, though the weight of some organs differed markedly owing to the parasitism of Cysticercus.

TABLE 2

Weight of Organs (mg per $100 \mathrm{~g}$ body weight)

\begin{tabular}{lccc}
\hline & Group A & Group B & Group C \\
\hline Liver & $3,754 \pm 383^{a}$ & $3,641 \pm 494$ & $3,885 \pm 775$ \\
Heart & $297 \pm 13$ & $307 \pm 14$ & $309 \pm 12$ \\
Spleen & $241 \pm 18$ & $237 \pm 25$ & $221 \pm 20$ \\
Kidney & $373 \pm 10^{b}$ & $368 \pm 15$ & $353 \pm 13$ \\
Adrenal gland & $9.7 \pm 0.5^{c}$ & $9.2 \pm 0.7$ & $8.8 \pm 0.9$ \\
Testis & $428 \pm 9$ & $431 \pm 11$ & $420 \pm 9$ \\
\hline
\end{tabular}

a Standard error. ${ }^{b}$ Average of both sides. $c$ Sum of both sides. 
Autopsy Findings: The autopsy findings of the rat bred for 6 months were shown in Table 3.

TABLE 3

Autopsy. Findings

\begin{tabular}{clc}
\hline \hline \multirow{2}{*}{ Group } & \multicolumn{1}{c}{ Findings } & Number of pathological cases \\
\cline { 2 - 3 } & & Number of autopsy \\
\hline \multirow{2}{*}{ A } & Parasitism of Cysticercus & $3 / 16$ \\
& Partial change of pulmonary lobe & $1 / 16$ \\
B & Parasitism of Cysticercus & $4 / 15$ \\
& Partial change of pulmonary lobe & $2 / 15$ \\
& Congestion of the adrenal medulla & $1 / 15$ \\
& Partial fibrin sedimentation of hepatic capsula & $1 / 15$ \\
C & Parasitism of Cysticercus & $2 / 16$ \\
& Partial change of pulmonary lobe & $1 / 16$ \\
\hline
\end{tabular}

Histological Findings: A summary of histological findings is shown in Table 4 .

TABLE 4

Histological Findings

\begin{tabular}{|c|c|c|}
\hline \multirow{2}{*}{ Group } & \multirow{2}{*}{ Histological change } & Number of pathological cases \\
\hline & & Number of observations \\
\hline \multirow[t]{4}{*}{$\mathrm{A}$} & \multirow{4}{*}{$\begin{array}{l}\text { Blood absorption in mesenteric lymphnodes } \\
\text { Mild catarrhal pneumonia } \\
\text { Infiltration of mono- and lymphocytes below } \\
\text { the pericardium } \\
\text { Infiltration of lymphocytes in hepatic Glisson } \\
\text { sheath } \\
\text { Mild fatty infiltration in the liver }\end{array}$} & $\begin{array}{r}12 / 16 \\
2 / 16\end{array}$ \\
\hline & & $1 / 16$ \\
\hline & & $2 / 16$ \\
\hline & & $1 / 16$ \\
\hline \multirow[t]{4}{*}{$\mathrm{B}$} & \multirow{4}{*}{$\begin{array}{l}\text { Blood absorption in mesenteric lymphnodes } \\
\text { Infiltration of mono- and lymphocytes in the } \\
\text { myocardium } \\
\text { Infiltration of lymphocytes in hepatic Glisson } \\
\text { sheath } \\
\text { Hypertrophy of hepatic capsule } \\
\text { Mild fatty infiltration in the liver } \\
\text { Mild catarrhal pneumonia }\end{array}$} & $12 / 15$ \\
\hline & & $1 / 15$ \\
\hline & & $1 / 15$ \\
\hline & & $\begin{array}{l}2 / 15 \\
2 / 15 \\
2 / 15\end{array}$ \\
\hline \multirow[t]{6}{*}{$\mathrm{C}$} & \multirow{6}{*}{$\begin{array}{l}\text { Blood absorption in mesenteric lymphnodes } \\
\text { Infiltration of lympho- and monocytes in heart } \\
\text { interstitium } \\
\text { Infiltration of lymphocytes in hepatic Glisson } \\
\text { sheath } \\
\text { Mild fatty infiltration in the liver } \\
\text { Infiltration of lympho- and monocytes in kidney } \\
\text { Atrophy of splenic medulla } \\
\text { Mild catarrhal pneumonia }\end{array}$} & $10 / 16$ \\
\hline & & $1 / 16$ \\
\hline & & $1 / 16$ \\
\hline & & $1 / 16$ \\
\hline & & $1 / 16$ \\
\hline & & $3 / 16$ \\
\hline
\end{tabular}

The observation of the chronic test of TMPDS during six months, 4 in group $A, 5$ in group $B$ and 4 in group $C$ died. This was caused by the mistake of injection or infection catarrh, but was not due to the drug itself. The difference in weight was observed between the groups temporarily because of the weight loss caused by pneumonic infection, but no significant difference was found between 
them throughout the six-month observation.

In autopsy and histological findings, the parasitism of Cysticercus fasciolaris and the pathological change due to infection catarrh were observed in all the groups. The blood absorption in the lymph sinus of the mesenteric lymph-node was seen in a high percentage, possibly due to the hemorrage caused by the intraperitoneal injection. A case of hypertrophy in the perihepatic membrane was seen in group $B$, but no degeneration of hepatic parenchyma was found, possibly caused by the physical stimulation during the injection. Other histological findings were in common to each group, and nothing specific to TMPDS was observed.

\section{Safety of TMPDS to the Fetus}

Methods - Animals: Wistar-King strain female rats (weighing 250-300 g) and ICR strain female mice (weighing $30-35 \mathrm{~g}$ ) were used. For obtaining the pregnant animals, a healthy male rat was placed in the cage with $4-5$ females in the evening. On the next early morning, the vaginal smear was taken and examined microscopically after Giemsa staining. The rat, whose vaginal smear showed the existence of the sperm, was regarded as pregnant. In mice, the animal having a vaginal plug was assumed to be pregnant. The observed day was defined as the first day of pregnancy. The breeding condition and the feed were the same as the chronic test.

Drugs, Dosage and Application: The animals were divided into 4 groups. Group $A$, receiving TMPDS corresponding to $50 \mathrm{mg} / \mathrm{kg}$, thiamine $\mathrm{HCl}$; group $B$, TMPDS $100 \mathrm{mg} / \mathrm{kg}$, group $C$, TMPDS $500 \mathrm{mg} / \mathrm{kg}$ and group $D, 1.5 \% \mathrm{NaHCO}_{3}$. They were administered intraperitoneally once a day for 8 successive days from the 7-14th day of pregnancy. In the control group, the same amount of the original solution without the vitamin as that of group $B$ was administered. The drug was dissolved in $1.5 \% \mathrm{NaHCO}_{3}$ solution. For $A$ and $B$ the concentration was $5 \mathrm{mg} / \mathrm{ml}$, and for $C 50 \mathrm{mg} / \mathrm{ml}$. The dosage was chosen as follows. In the acute toxicity test, after intraperitoneal injection more than $5 \mathrm{~g} / \mathrm{kg}$, the convulsive seizure appeared and the animlas died with the symptoms of muscle relaxation and hydrocele testis. With the dose less than $5 \mathrm{~g} / \mathrm{kg}$, only a slight inhibition of voluntary movement was observed. Accordingly, the minimum lethal dose of TMPDS was assumed to be about $5 \mathrm{~g} / \mathrm{kg}$, and $500 \mathrm{mg} / \mathrm{kg}, 1 / 10$ of the minimum lethal dose, was assumed to be the maximum dose for teratological test of sucessive 8 day administration.

Observation Period and Procedure: A half of each group was sacrificed under ether anesthesia, and laparotomy was performed. After taking out the fetuses, their total numbers, surviving and dead, including absorbed fetuses and retained plancenta, were determined. The weight of the surviving fetuses was measured immediately and the abnormalities in the external appearance was observed. After fixing in 70\% alcohol, the skeletal preparation was made by Dawson's method (1). The remaining half of the gestated rats were allowed to deliver naturally, and the abnormalities in the external appearance was observed. Therefore, the growth of the new-born animals was observed for 20 days. They were then sacrificed under ether anesthesia and the abnormalities in the external appearance and organs were examined. The skeletal preparation was similarly made. In mice, laparotomy was performed at 18 days' gestation and treated 
further as described above.

Results Effect on the Fetuses of Rats: As shown in Table 5, no significant differences were found in survival and death numbers, and weights among the groups. In external observation, only one case with brachygnathia and syndactyly was observed in group $B$. In the skeletal preparations, 2 cases of flexed rib appeared in group $A$, and one in group $B$. The anomaly of rib number such as the defect and trace of 13th rib and the appearance of 14th rib, as known to appear spontaneously, was seen in one case in group $A, 2$ cases in group $B, 2$ cases in group $C$ and 3 cases in group $D$. These abnormalities, however, showed no significant differences among the groups.

TABLE 5

Effects of TMPDS on the Fetuses of Rats and Mice

I, number of gestated animals; II, average number of fetuses of one gestated animal; III, number of average surviving fetuses of one gestated animal; IV, number of dead fetuses; V, average body weight of fetuses; VI, external abnormality; VII, skeletal abnormality; VIII, kind of abnormality (in number of cases).

\begin{tabular}{|c|c|c|c|c|c|c|c|c|}
\hline Group & I & II & III & IV & $\mathrm{V}$ & VI & VII & VIII \\
\hline & & & & er cent & $\begin{array}{l}g \\
\text { Rats }\end{array}$ & per & cent & \\
\hline $\mathrm{A}$ & 10 & $10.8 \pm 0.7^{a}$ & $10.1 \pm 0.7$ & 6.5 & $2.80 \pm 0.10$ & - & 3.0 & \multirow{4}{*}{$\begin{array}{l}\text { Flexed rib (2) } \\
\text { Anomaly in the } 13 \text { th rib (1) } \\
\text { Flexed rib (1) } \\
\text { Anomaly in the } 13 \text { th rib (2) } \\
\text { Brachygrathia and } \\
\text { Anomaly in the } 14 \text { th rib (1) } \\
\text { Anomaly in the 13th rib (1) } \\
\text { Anomaly in the 13th rib (1) }\end{array}$} \\
\hline $\mathrm{B}$ & 11 & $10.5 \pm 0.8$ & $9.9 \pm 0.9$ & 6.0 & $2.61 \pm 0.22$ & 0.9 & 2.7 & \\
\hline $\mathrm{C}$ & 8 & $8.8 \pm 0.8$ & $8.3 \pm 1.0$ & 5.7 & $2.79 \pm 0.26$ & - & 2.8 & \\
\hline D & 10 & $10.2 \pm 0.4$ & $9.3 \pm 0.3$ & 8.8 & $\begin{array}{c}2.57 \pm 0.10 \\
\text { Mice }\end{array}$ & - & 3.2 & \\
\hline $\mathrm{A}$ & 12 & $10.8 \pm 0.5$ & $10.2 \pm 0.4$ & 5.4 & $1.09 \pm 0.03$ & - & 4.1 & \multirow{4}{*}{$\begin{array}{l}\text { Cervical rib (4) } \\
\text { Anomaly in the } 13 \text { th rib (1) } \\
\text { Cervical rib (3) } \\
\text { Anomaly in the } 13 \text { th rib (1) } \\
\text { Imperfect adhesion of } 6 \text { th } \\
\text { Cervical rib (2) stemum (1) }\end{array}$} \\
\hline B & 10 & $9.8 \pm 0.6$ & $9.1 \pm 0.4$ & 7.1 & $1.08 \pm 0.03$ & - & 5.5 & \\
\hline $\mathrm{C}$ & 11 & $10.0 \pm 0.9$ & $9.1 \pm 0.8$ & 7.8 & $1.10 \pm 0.03$ & 0.9 & 3.6 & \\
\hline $\mathrm{D}$ & 10 & $10.4 \pm 1.6$ & $9.5 \pm 0.5$ & 8.6 & $1.07 \pm 0.03$ & - & 3.2 & \\
\hline
\end{tabular}

a Standard error.

Effect on the New-born Animals: As shown in Tables 6 and 7, no significant differences were found between among the groups in the number of newborn and weaning animals, survival rate and growth rate. No abnormalities were detected in the external and skeletal examinations done immediately and 20 days after birth. The growth rate in the drug-administered group showed a slightly lower value compared with that of the control. It is possibly due to the fact that all the fetuses were killed by the mother animal in $A$ and $B$ group.

Effect on the Fetuses of Mice: As shown in Table 5, no significant differences were found in the survival and death numbers and weights among 
TABLE 6

Effects of TMPDS in Newborn Rats and Mice

I, number of gestated animals; II, number of newborns delivered by one animal; III, number of weaning animals; IV, growth rate; V, sex ratio (male/female); VI, external anomaly; VII, skeletal anomaly; VIII, organ anomaly; IX, kind of anomaly (number of cases).

\begin{tabular}{|c|c|c|c|c|c|c|c|c|c|}
\hline Group & I & II & III & IV & $\mathrm{V}$ & VI & VII & VIII & IX \\
\hline & & & \multicolumn{3}{|c|}{ per cent } & \multicolumn{3}{|c|}{ per cent } & \\
\hline \multicolumn{10}{|c|}{ Rats } \\
\hline A & 8 & 9.9 & 8.0 & 81 & $42 / 58$ & 0 & 0 & 0 & \\
\hline $\mathrm{B}$ & 7 & 9.0 & 6.7 & 75 & $49 / 51$ & 0 & 0 & 0 & \\
\hline $\mathrm{C}$ & 7 & 8.1 & 6.7 & 82 & $53 / 47$ & 0 & 0 & 0 & \\
\hline $\mathrm{D}$ & 10 & 10.1 & 8.9 & 88 & $55 / 45$ & 0 & 0 & 0 & \\
\hline \multicolumn{10}{|c|}{ Mice } \\
\hline $\mathrm{A}$ & 11 & 9.2 & 7.6 & 83 & $48 / 52$ & 0 & 3.6 & 0 & Anomaly in the 13 th rib (3) \\
\hline $\mathrm{B}$ & 14 & 9.8 & 7.5 & 77 & $45 / 55$ & 0 & 5.7 & 1.9 & $\begin{array}{l}\text { Anomaly in the } 13 \text { th rib }(6) \\
\text { Hydronephrosis }(2)\end{array}$ \\
\hline C & 10 & 9.7 & 7.2 & 74 & $45 / 55$ & 0 & 4.2 & 0 & Anomaly in the 13th rib (3) \\
\hline $\mathrm{D}$ & 9 & 9.6 & 7.5 & 78 & $46 / 54$ & 0 & 7.5 & 1.5 & $\begin{array}{l}\text { Anomaly in the } 13 \text { th rib } \\
\text { Hydronephrosis }(1)\end{array}$ \\
\hline
\end{tabular}

TABLE 7

Weight Change in New-born Rats and Mice

\begin{tabular}{|c|c|c|c|c|c|c|c|c|c|c|c|}
\hline \multirow{3}{*}{ Group } & \multirow{3}{*}{$\begin{array}{l}\text { No. of } \\
\text { gestated } \\
\text { animals }\end{array}$} & \multirow{2}{*}{\multicolumn{2}{|c|}{$\begin{array}{l}\text { Time of } \\
\text { derivery }\end{array}$}} & \multicolumn{8}{|c|}{ Days after birth } \\
\hline & & & & \multicolumn{2}{|r|}{5} & \multicolumn{2}{|r|}{10} & \multicolumn{2}{|r|}{15} & \multicolumn{2}{|r|}{20} \\
\hline & & No. & Weight & No. & Weight & No. & Weight & No. & Weight & No. & Weight \\
\hline & & & $g$ & & $g$ & & $g$ & & $g$ & & $g$ \\
\hline \multicolumn{12}{|c|}{ Rats } \\
\hline A & 8 & 79 & $5.1 \pm 0.4^{a}$ & 70 & $11.0 \pm 1.3$ & 68 & $16.1 \pm 1.3$ & 66 & $22.3 \pm 2.1$ & 64 & $27.4 \pm 2.6$ \\
\hline B & 7 & 63 & $5.6 \pm 0.4$ & 48 & $10.0 \pm 0.4$ & 48 & $15.8 \pm 1.4$ & 47 & $22.0 \pm 2.1$ & 47 & $29.6 \pm 3.7$ \\
\hline $\mathrm{C}$ & 7 & 57 & $5.2 \pm 0.5$ & 52 & $9.4 \pm 0.9$ & 50 & $15.1 \pm 1.8$ & 49 & $24.5 \pm 2.6$ & 47 & $30.8 \pm 3.5$ \\
\hline $\mathrm{D}$ & 10 & 101 & $5.7 \pm 0.5$ & 91 & $10.8 \pm 1.4$ & 90 & $15.7 \pm 1.6$ & 89 & $23.0 \pm 3.5$ & 89 & $28.1 \pm 3.6$ \\
\hline \multicolumn{12}{|c|}{ Mice } \\
\hline A & 11 & 101 & $1.46 \pm 0.03$ & 89 & $2.71 \pm 0.15$ & 88 & $4.54 \pm 0.18$ & 85 & $5.92 \pm 0.25$ & 84 & $7.91 \pm 0.47$ \\
\hline B & 14 & 137 & $1.43 \pm 0.05$ & 113 & $2.87 \pm 0.08$ & 110 & $4.68 \pm 0.19$ & 109 & $6.09 \pm 0.28$ & 105 & $8.31 \pm 0.38$ \\
\hline C & 10 & 97 & $1.56 \pm 0.05$ & 82 & $2.80 \pm 0.13$ & 75 & $5.00 \pm 0.23$ & 75 & $6.28 \pm 0.35$ & 72 & $8.26 \pm 0.44$ \\
\hline $\mathrm{D}$ & 9 & 86 & $1.63 \pm 0.04$ & 81 & $2.83 \pm 0.11$ & 79 & $4.88 \pm 0.21$ & 71 & $6.27 \pm 0.34$ & 67 & $8.05 \pm 0.36$ \\
\hline
\end{tabular}

$a$ Standard error. No significant difference was detected by $t$-test among TMPDS group and the control.

the groups. Only one case of tail anomaly was observed in external examination. In the observations of skeletal preparations, cervival rib was found $3.3 \%$ in group $A, 3.3 \%$ in $B, 1.8 \%$ in $C$ and $3.2 \%$ in $D$. The anomaly in the 13 th rib was seen in one case in group $A$, in one case in $B$, in 2 cases in $C$, a finding about the same as in the case of rats. Besides, imperfect union of sterum was observed in one case in group $B$.

New-born Mice: As shown in Tables 6 and 7, no significant differences were observed in the number of the new-born and weaning animals, the growth rate and weight change among the groups. No abnormalities were also found in external examination. In skeletal examination, the anomaly in the 13 th rib was 
found in 3 cases in group $A, 6$ cases in group $B, 3$ cases in group $C$ and 5 cases in group $D$. In autopsy findings, hydronephrosis was seen in 2 cases in group $B$ and in one case in group $C$.

\section{DISCUSSION}

No significant differences were found in the survival and death numbers of the futuses and their weight between the TMPDS-administered group and the control. As the occurrence of brachygnathia, syndactyly and flexed rib in rats and that of the anomaly of the tail and imperfect union of sternum in mice were very poor, and the rate of death, absorption, external and skeletal malformations were in good agreement with the data from the Central Laboratory of Experimental Animals. These abnormalies were not caused by the drug, but are assumed to be spontaneous. In new-born rats and mice, no significant differences were observed in the number of delivery and weaning, growth rate, body weight change among the groups, and no effect of TMPDS on the new-born animals could be detected. The occurrence of hydronephrosis mice was very poor and cannot be attributed to the action of the drug.

\section{SUMMARY}

Safety examinations of thiamine monophosphate disulfide (TMPDS) was performed by chronic toxicity and teratological tests and obtained the following findings.

1. In the chronic toxicity test, TMPDS was administered to rats intraperitoneally in doses of 100 and $50 \mathrm{mg} / \mathrm{kg}$ daily for six months. No significant differences among the groups were observed in the body weight gain, food intake, organ weights and hematological and histological findings.

2. In the teratological test, 500,100 and $50 \mathrm{mg} / \mathrm{kg}$ of TMPDS were administered intraperitoneally to gestated rats and mice every day from the 7 th to 14 th day of gestation. No effects of TMPDS was observed on both fetuses and new-borns from the mother animals.

\section{REFERENCES}

1. Wright, H. V., Asling, C.W., Dougherty, H. L., Nelson, M.M., and Evans, H.M., Anat. Rec. 130, 659 (1958).

2. Report on ICR-JCL Mice, Central Laboratories for Experimental Animals, Tokyo (1964). 